\title{
Kazak Türkçesinde Zarf-Fiil Kökenli Kipler
}

\section{Süleyman EFENDİOĞLU}

Özet

Günümüz Türkiye Türkçesinde hiç de alışık olmadığımız içinde zarf-fiil bulunan veya zarf-fiilden oluşma kip şekilleri, aslında Eski Türkçe döneminden bu yana gerek tarihî lehçelerimizde gerekse çağdaş lehçelerimizde daima karşımıza çıkmaktadır. Bu tarz kipler, günümüzde özellikle Kuzey-Batı (Kıpçak) grubu Türk lehçelerinde bulunmakta; Kuzey-Batı lehçelerinin arasında da daha ziyade Kazak Türkçesinde görülmektedir. Tespitlerimize göre bugün Kazak Türkçesinde yedisi basit, ikisi birleşik çekim olmak üzere toplam dokuz kip bu yapıdadır. Makalede söz konusu kipler etimolojik tetkiklerle dikkatlere sunulacaktır.

Anahtar Kelimeler: Türk Dili, Kazak Türkçesi, Kip, Zaman, Zarf-Fiil

\section{Modes Originated From Gerund In Kazakh Turkish}

\begin{abstract}
Mode forms constructed by gerund that we are barely used to in Turkey Turkish have always been existed not only in our contemporary but also in our historical dialects since Ancient Turkish period. These modes derivated by gerund especially exist in North-West (Kipchak) Turkish Dialects now; and among North-West dialects it is mostly seen in Kazakh Turkish rather than the others. According to our findings totally nine modes- seven of them are in basic declension, two of them are in compound declension- are in this form. These mentioned modes will be explained in terms of historical etymological findings.
\end{abstract}

Key Words: Turkish Language, Kazakh Turkish, Mode, Tense, Gerund

\section{Giriş}

Türk lehçelerini sınıflandırmada çoğu zaman temel ölçü kabul edilen üçlü etnik tasnife (Oğuz, Karluk, Kıpçak) göre Kazak Türkçesi, öteden beri tüm yerli ve yabancı dil bilginleri tarafından eski Kıpçak Türkçesinin bir devamı şeklinde değerlendirilmiş ve "Kıpçak", "Kuzey”, "Kuzey-Batı" grubu adlarıyla anılan Türk Lehçeleri grubuna dâhil edilmiştir. (Buluç, 1988: 456-468; Yüce, 1988: 468-530). Tarih içinde çok yayılmış olan Kıpçakların adını taşıyan dil alanı, Türk dili haritasında geniş bir yer tutmaktadır. Karadeniz'in kuzeyinden Sibirya'ya ve Tanrı Dağları'na kadar yayılan topraklar, bugün Kıpçak lehçelerinin konuşulduğu veya yazı dili olarak kullanıldığı alanı teşkil

\footnotetext{
${ }^{a}$ Yard. Doç. Dr., Atatürk Üniversitesi, Edebiyat Fakültesi, s.efendioglu@hotmail.com , Erzurum
} 
etmektedir. Günümüz Kıpçak lehçeleri arasında Kazak Türkçesi haricinde şu çağdaş lehçeler de yer almaktadır: Karaim (Karay) Türkçesi, Kırım-Tatar Türkçesi, Karaçay-Balkar Türkçesi, Kumuk Türkçesi, Tatar Türkçesi, Başkurt Türkçesi, Karakalpak Türkçesi, Nogay Türkçesi, Kırgız Türkçesi (Öner, 1998: XIII-XXIII). Sonuç olarak bugün Kazak Türkçesi, ağırlıklı olarak eski Kıpçak dilinin özelliklerini göstermesinin yanında Göktürk metinlerinin dilini de iyi yansıtan ve yer yer Çağatay Türkçesinin izlerini taşıyan önemli bir lehçemizdir.

Kip konusuna gelince bugün Türkçede kip (mood) ya da kiplemenin (modality) ne olduğu konusunda çok çeşitli ve birbiriyle çelişen farklı görüşler olduğunu biliyoruz. Birçok gramer mevzumuzda olduğu gibi bu meselede de bir mutabakat sağlanabilmiş veya sorun çözüme kavuşturulmuş değildir. Kipi, fiilin gösterdiği hareketin nasıl yapıldığını bildiren bir biçim veya tarz olarak kabul eden görüşlerin yanında kip ile zamanı iç içe düşünen ve bunları birbirinden ayırmayıp zamanı kip gibi değerlendiren görüşler de vardır. Bazı dilbilgisi kitaplarında da kip, eylem, zaman ve şahıs kavramlarının bileşkesi olarak verilmiştir. ${ }^{1}$ Hele birleşik zaman çekimlerinde veya fiillerin birleşik çekimlerinde durum daha da karışıktır. Çünkü bu birleşiklerde gerçekten çift zaman mı vardır ya da birleşik çekimlerdeki eklerden hangisi zaman, hangisi kip ifade etmektedir bunlar bile hâlâ çözüm beklemektedir (Gülsevin, 2000: 215-224).

Bütün bu karışıklığa rağmen biz kip kavramına fiillerin zaman ve tarzlara göre türlü biçimbirimlerle girdikleri kalıplar gözüyle baktık. Kazakçadaki kipleri de bu mantıkla irdeledik. Buna göre Kazak Türkçesinin "kip tablosu” şu şekilde karşımıza çıkmaktadır:

\section{A) BASITT KİPLER}

\section{Bildirme Kipleri:}

1. Görülen Geçmiş Zaman Kipi

- /-DI/ ekli görülen geçmiş zaman kipi

(bastadım "başladım", berdim "verdim", aştım "açtım", kettim "gittim")

- /-GAn/ ekli görülen geçmiş zaman kipi

\footnotetext{
${ }^{1}$ Kip konusundaki tartı̧̧malar ve farklı görüşler için bkz.: Türk Gramerinin Sorunları II, "Türkçede Fiil ve Fiil Cekimi", TDK Yay., Ankara-1999, s.45-112.

Neşe ATABAY, Sevgi ÖZEL, İbrahim KUTLUK, (Yöneten ve Yayıma Hazırlayan: Doğan AKSAN); Sözcük Türleri, Papatya Yay., İstanbul-2003, s.201-215.

Zeynep KORKMAZ; Türkiye Türkçesi Grameri (Şekil Bilgisi), TDK Yay., Ankara-2003, s.567-573.

2 Bakabildiğimiz tüm kaynaklarda /-GAn/ ekli kip, görülen geçmiş zaman kipi olarak verildiği halde "Türk Lehçeleri Grameri" adlı çalışmada bu yapı öğrenilen geçmiş zaman kipi olarak
} 
Efendioğlu, S. / Sosyal Bilimler Araştırmaları Dergisi. 1, (2010): 1-20

(alğanmın "aldım”, üyrengenmin “öğrendim”, japkanmın "kapattım", köşkenmin "göçtüm")

- /-AtIn/, /-ytIn/ ekli görülen geçmiş zaman kipi** (aşatınmın "açtım, açardım", oylaytınmın "düşündüm, düşünürdüm"3

\section{2. Öğrenilen Geçmiş Zaman Kipi}

- /-(I)p/ ekli öğrenilen geçmiş zaman kipi* (urıppın "vurmuşum", bilippin "bilmişim")

\section{3. Şimdiki Zaman Kipi}

- /-A/, /-y/ ekli şimdiki zaman kipi*

(alamin "alıyorum", egemin "ekiyorum", isteymin "işliyorum") ${ }^{4}$

- [/-(I)p/, /-A/, /-y/ + /otır-/, /jatır-/, /tur-/, /jür-/] kalıplı şimdiki zaman kipi*

(jazıp otırmın "yazıyorum", körip jatırmın "görüyorum", tıñdap tur "dinliyor", pisirip jürmin "pişiriyorum", söyley otırmın "konuşuyorum", köre jatırmın "görüyorum", kele jürmin "geliyorum", okıy turmın "okuyorum")

- /-(U)wdA/ ekli şimdiki zaman kipi

değerlendirilmiştir. Ancak hareketin kesin olarak yapıldığını bildirdiğinden bazı durumlarda görülen geçmiş zaman kipi olarak da değerlendirilebileceği söylenmiştir: oylağanmın “düşünmüşüm/düșündüm”, tüsingenmin “anlamışım/anladım”, kütkenmin "beklemişim/bekledim” gibi (Ercilasun, 2007: 461). Ayrıca Ayşe TEKIN, "Kazak Türkçesinde Sifat-Fiil ve Zarf-Fiil Ekleri" isimli yüksek lisan tez çalışmasında/-GAn/ ekli kipin, görülen geçmiş zamanın yanında öğrenilen geçmiş zaman, geniş zaman hatta şimdiki zaman olarak da kullanıldığını belirtmiş ve çeşitli örneklerle görüsünü desteklemiștir (Tekin 2006: 36).

(*) Bu işaret yanında bulunduğu kipin zarf-fiil soylu olduğunu belirtmektedir.

3 /-AtIn/, /-ytIn/ ekli görülen geçmiș zaman kipinin ilave edildiği fiil, Türkiye Türkçesinde geniș zamanın hikâye çekiminde kazandığı anlama benzer bir anlam da kazanır: oynaytınmın "oynardım"; baratınsıñ "giderdin"; aytatın "söylerdi"; ișetinsiñder "içerdiniz"; biletinsiz "bilirdiniz"; jeytinbiz "yerdik" (bkz. KOÇ vd., 2004: 257).

${ }^{4} \mathrm{Bu}$ şekil gelecek zaman ve geniş zaman anlamı da vermektedir (bkz. Buran vd. 2001: 206; Ercilasun vd., 1991: 1054-1055; Öner 1998: 172-181). Hatta bu yüzden Kazak Türkçesinde "değişken şimdiki zaman” anlamında "awıspalı osı şaq" diye adlandırılır (bkz. Ercilasun, 2007: 462).

${ }^{5}$ Bunlardan otır ile yapılan şimdiki zaman, hareketin şu anda yapılmakta olduğunu anlatır: jazıp otırmın "şu anda yazıyorum". Jatır ile yapılan şimdiki zamanda; zaman düne, bugüne, yarına yayılmıștır: jazıp jatırmın "dün de yazıyordum, bugün de yazıyorum, yarın da yazmağa devam edeceğim". Tur ile yapılan șimdiki zaman, hareketin kısa aralıklarla fakat devamlı olarak yapıldığını anlatır: jazıp turmın "yazıp duruyorum". Jür ile yapılan şimdiki zamanda da devamllık vardır, fakat işe bir süre ara verilmiştir; aslında iş yapılmaya devam edecektir: jazıp jürmin "unutmadım yazıyorum, yazmağa devam edeceğim" (bkz. Ercilasun vd., 1991: 1055). 
Efendioğlu, S. / Sosyal Bilimler Araştırmaları Dergisi. 1, (2010): 1-20

(jazuvdamın "yazıyorum, yazmaktayım", hattawdamın "kaydediyorum, kaydetmekteyim", kelüwdemin "geliyorum, gelmekteyim", uyıktawdamın "uyumaktayım, uyuyorum"6

4. Gelecek Zaman Kipi

- /-A/, /-y/ ekli gelecek zaman kipi* üyretemin "öğreteceğim”, aytamın "söyleyeceğim”, okıymın "okuyacağım"

- [/-GAII/ + /otır-/, /jatır-/, /tur-/, /jür-/] kalıplı gelecek zaman kipi (Yakın gelecek zaman kipi)

aşkalı otırmın "(yakında) açacağım”, tikkeli jürmin “(yakında) dikeceğim”, barğalı jatırmın "(yakında) gideceğim”, jatkalı otırmın "(birazdan) yatacağım"

- /-mAk(şI)/, /-BAk(şI)/ ekli gelecek zaman kipi (Niyet ifadeli gelecek zaman kipi) ${ }^{7}$

almakpın "alacağım (almak niyetindeyim)", kezbekşimin "gezeceğim (gezmek niyetindeyim)", aytpakşımın "söyleyeceğim (söylemek niyetindeyim), körispekpin "görüşeceğim (görüşmek niyetindeyim)"

- /-Ar/, /-r/ ekli gelecek zaman kipi (Belirsiz gelecek zaman kipi) ${ }^{8}$

bararmın "gideceğim", kelermin "geleceğim”, kararmın "bakacağım"

\section{Geniş Zaman Kipi ${ }^{9}$}

- /-A/, /-y/ ekli geniş zaman kipi*

${ }^{6}$ Türkiye Türkçesindeki -makta, -mekte ekinin hem yapı, hem de temel fiile kattı̆̆ı anlam açısından birebir karşılı̆̆ 1 olan $-(u) w d a$, $-(\ddot{u}) w d e$ eki; $/-w /$ mastar eki ile bulunma hâli ekinin birleşiminden oluşmaktadır. Bu tür şimdiki zamanlar; (fiil+/-(U)wdA/+kişi eki) formülüyle yapılır (bkz. KOÇ vd., 2004: 265).

${ }^{7}$ Bazı kaynaklarda bu yapı, istek kipinin bir çeşidi olarak da verilmiştir: kek almakşımın "öç alayım”, tökpekşimin “dökmek istiyorum” (Öner, 1998: 203-206; Buran vd., 2001: 210).

${ }^{8}$ Belirsiz gelecek zaman da diyebileceğimiz bu yapı, fiile Türkiye Türkçesinde temel olarak geniş zaman eki olarak kullanılan -ar, -er, -r ekinin "yarın belki gelirim" cümlesinde verdiği anlamı verir. Bu zaman çekimi ; (fiil $+/-A r / / /-r /$; /-mAs/+kişi eki) formülüyle yapılmaktadır. "öziñiz eveli kelersiz" (siz önce gelirsiniz/geleceksiniz), "şeşeme osılay aytarsın" (anneme böyle söylersin/söyleyeceksin), "kaytarmız" (geri döneriz/geri döneceğiz) (Koç vd. 2004: 269). Ayrıca bu /-Ar/,/-r/ ekli gelecek zaman yapısı Kazak Türkçesinde aynı zamanda geniş zaman kipini de oluşturmaktadır (Doğan vd. 2007: 206).

${ }^{9}$ Önemli birçok Tatar, Kazak ve Kırgız gramer kitaplarının fiil çekiminde geniş zaman bahsi yoktur. Sadece şimdiki zaman ve gelecek zaman çekiminde yapının geniş zaman fonksiyonuna atıflar yapılmaktadır. (bkz. İskakov 1991; Hangildin 1959; İsabekova vd. 2001; Oruzbayeva vd. 1964; Davlatov vd. 1980; Çengel 2005). Bunun yanında redaktörlüğünü Ayabek BAYNIYAZOV'un yaptığ 1 "Kazak Türkçesi Grameri" adlı kitapta -ar, -er, -r ekli kipin atasözleri dışında Kazak Türkçesinde kesinlikle geniş zaman anlamı taşımadı̆̆ 1 ; Kazakçada geniş zaman kipinin sadece $-a$, $-e,-y$ ekleriyle ve (fiil+/-A/, /-y/+kişi eki) formülüyle ifade edildiği ileri sürülmektedir (bkz. Koç vd. 2004: 269-274). 
Efendioğlu, S. / Sosyal Bilimler Araştırmaları Dergisi. 1, (2010): 1-20

tabamin "bulurum", ötemin "geçerim", söyleymin "konuşurum", tileymin "isterim, arzu ederim" "10"

- /-Ar/, /-r/ ekli geniş zaman kipi ${ }^{11}$ andarmın "anlarım", surarmın "sorarım", kelisermin "anlaşırım”, juwınarmın (yıkanırım), sozarmın "uzatıım”, üzermin "koparırım"

\section{Tasarlama Kipleri:}

1. İstek Kipi

- /-GAy/ ekli istek kipi

barğaymın "varayım", bergeymin "vereyim", aytkaymın "söyleyeyim", işkeymin "içeyim"

- $\quad[/-G I /$ + /iye/ + /keledi// kalıplı istek kipi (Yardımcı fiilli istek)

barğım keledi "gidesim gelir/gideyim/gitmek istiyorum", tüsingim keledi "anlayasım geldi/anlayayım/anlamak istiyorum", tapkım keledi "kazanasım geldi/kazanayım/kazanmak istiyorum", erkeletkisi keledi“"gönlünü alasım geldi/gönlünü alayım/gönlünü almak istiyorum"

\section{Emir Kipi}

Bu kalıpta şahıs ekleriyle kip ekleri iç içe girmiştir. Fiil kök veya gövdesine getirilen şahıs ekleri aynı zamanda kipi de karşıladığından ayrıca özel bir kip eki kullanılmaz. Böylece Kazak Türkçesinin emir kipinde her şahıs için ayrı bir ek bulunur:

I. tekil şahıs: -AyIn, -yIn basta-yın "başlayayım”, kör-eyin "göreyim"

II. tekil şahıs $\quad: \varnothing$ basta- "başla-", kör- "gör-"

nezaket $\quad:-$ ñIz

III. tekil şahıs $\quad:$-sIn basta-ñız "başlayınız”, kör-(i)ñiz "görünüz"

${ }^{10}$ Mustafa ÖNER, kitabında /-A/, /-y/ ekli geniş zamanı "şimdiki zaman ifadeli geniş zaman" ve "gelecek zaman ifadeli geniş zaman" başlıkları altında işleyerek bu kipin şimdiki zaman ve gelecek zaman işlevlerine önemli bir vurgu yapmıştır. (bkz. Öner 1998: 174-177).

11 /-Ar/, /-r/ ekli geniş zaman kipi, "Karșllașttrmalı Türk Lehçeleri Sözlüğü" ve "Türk Lehçeleri Grameri” gibi önemli eserlerimizde "gelecek zaman kipi (belirsiz gelecek zaman veya tahmini gelecek 
Efendioğlu, S. / Sosyal Bilimler Araştırmaları Dergisi. 1, (2010): 1-20

$$
\begin{aligned}
& \text { basta-sın "başlasın", kör-sin "görsün" } \\
& \text { I. çoğul şahıs } \quad \text { : -AyIk, -yIk } \\
& \text { basta-yık "başlayalım", kör-eyik "görelim" } \\
& \text { II. çoğul şahıs } \quad:- \text { ñdAr } \\
& \text { basta-ñdar "başlayın", kör-(i)ñder "görün" } \\
& \text { nezaket } \quad: \text {-ñIzdAr } \\
& \text { basta-ñızdar "başlayınız", kör-(i)ñizder } \\
& \text { "görünüz" } \\
& \text { III. çoğul şahıs : : -sIn } \\
& \text { basta-sın "başlasınlar", kör-sin "görsünler" }
\end{aligned}
$$

\section{3. Şart Kipi*}

Kazak Türkçesinde şart kipi /-sA/ ekiyle yapılır: "göndersem"12

kalasam "istesem", desem "desem", alsam "alsam", jibersem

\section{Gereklilik Kipi}

- $\quad[/-(\mathbf{U}) \mathbf{v} /+$ /iye/ + /kerek/] kalıplı gereklilik kipi jazuvım kerek "yazmam gerek/yazmalıyım", okıvım kerek "okumalıyım"

tıñdavım kerek "dinlemeliyim", oylavım kerek "düşünmeliyim"

- $\quad[/-(\mathbf{U}) \mathbf{v} /+/$ iye/ + /tiyis(ti)/] kalıplı gereklilik kipi

kıluvım tiyisti "yapmalıyım", körüvim tiyis "görmeliyim" aluvım tiyisti "almalıyım", bilüvim tiyis "bilmeliyim"13

\section{B) BİRLEŞİK KİPLER}

\section{I.Hikâye}

Kazak Türkçesindeki bu birleşik çekim, Eski Türkçedeki er- ek fiilinin /-DI/ görülen geçmiş zaman ekiyle kurulmuş şekli olan erdi'nin, çağdaş

zaman)" olarak değerlendirilmiştir: alarmın "alırım (alacağım anlamında)", aytarmın "söylerim (söyleyeceğim anlamında)" (bkz. Ercilasun vd. 1991: 1056; Ercilasun 2007: 464).

${ }^{12}$ Kazak Türkçesinde şart kipi, fiillerin şart șeklinden başka geniş zamanın şartını da ifade eder: kalasam "istesem/istersem", desem "desem, dersem". Hangi şekli ifade ettiği cümlenin gelişinden anlaşllır (bkz. Ercilasun, 2007: 468). Ayrıca şart çekiminin sonuna -șı, -şi ekleri gelebilir. Bu ekler fiile I. ve III. şahıslarda pişmanlık; II. şahıslarda rica ve emir anlamı katar: alsamşı "alsaydım ya", kelseşi "gelseydi ya", alsañş1 "alsana", bilseñderşi "bilsenize". Yine şart çekimin sonuna goy, koy kelimesi eklenebilir. Bu da rica ve arzu ifade eder: alsam goy "keşke alsam", körsek koy "keşke görsek", jazsañdar goy "keşke yazsanız" gibi (bkz. Ercilasun vd., 1991: 1057).

13 Bazı kaynaklarda, kerek ve tiyis kelimelerinin dışında kajet kelimesiyle de gereklilik kipinin oluşturulabildiği belirtilmiştir: aytuvım kajet "söylemeliyim", kelüvim kajet "gelmeliyim" gibi. (Doğan vd., 2007: 213; Koç vd., 2004: 281-282). 
Kazakçadaki uzantısı olan edi ile yapılır. "edi” Türkiye Türkçesindeki ek fiilin görülen geçmiş zaman çekiminin (idi) karşıllğıdır: okığan edim "okumuştum”, bakkan jok edi "bakmamıştı", solıp ketip edi "solmuştu", suramak edim "soracaktım”, tüsirgeli jatır edi "indirmek üzereydi”, jürsek kerek edi “yürümeliydik” (Koç vd. 2004: 287-288).

\section{Rivayet*}

$\mathrm{Bu}$ çekim, Eski Türkçedeki erken yapısının çağdaş Kazakçadaki uzantısı olan eken ile yapılır. Bu yapı, Türkiye Türkçesindeki ek fiilin öğrenilen geçmiş zaman çekiminin (imiş) karşılığıdır (Koç vd. 2004: 297). Kazakçada nasıl ki hikâye çekimi $e$ - fiilinin görülen geçmiş zaman çekiminden ibaretse; rivayet çekimi de $e$ - fiilinin (ek eylemin) -gan ekli geçmiş zaman (öğrenilen geçmiş zaman) çekimidir (Öner 1998: 211). Jatır eken "yatıyormuş", aytıp otır eken "söylüyormuş", söylespek eken "konuşacaklarmış", baylamakşı eken "bağlayacakmış", alsam eken "alsaymışım", alğan ekenbin "almışmışım"

\section{III. Şart*}

Şart birleşik çekimi, kip eklerinden sonra bol- fiilinin şartının çekimiyle elde edilir. alğan bolsam "almış olsam/almışsam", sezgen bolsa "sezmişse", alar bolsam "alırsam", keter bolsan "gideceksen", alıspas bolsa "savaşmazsa", ayıptav kerek bolsa "suçlamak gerekirse", bilip jürgen bolsam "biliyorsam", kelüvde bolsam "geliyorsam"

Kazak Türkçesinin kip çekimi genel hatlarıyla bu şekildedir. Dikkatlice incelendiğinde bunlardan yıldızla işaretlenmiş olanların zarf-fiil kökenli oldukları göze çarpacaktır. Fakat "zarf-fiil kökenli kipler" ifadesinin sadece zarf-fiil eklerinden oluşma kiplerle sınırlı olmadığını belirtelim. Bu ifade, kökeninde bir zarf-fiil eki de bulunan daha karmaşık yapılı kipleri de kapsamaktadır. Ancak içinde zarf-fiilin haricinde başka unsurların bulunduğu kiplerde bile asıl işlevin zarf-fiil ekinde gizli olduğu açıktır. Çünkü diğer unsurların Türkçenin gelişim süreci içerisinde genelde aşınarak düştüğü ve oradaki zarf-fiilin çoğu zaman tek başına gramatikalleşerek kiplik değere ulaştı̆g 1 ortadadır (Ör. alıp turur men>aliptur men>alipmen>alippen>alippin "almışım” gibi). Kaldı ki zarf-fiil ekleri, üzerine ulandığı fiille beraber fiilimsi (zarf-fiil) meydana getirdiğinden burada inceleyeceğimiz kiplerin hepsini zarf-fiil soylu kabul etmek zorundayız.

Türkiye Türkçesinde hiç de alışı olmadığımız içinde zarf-fiil bulunan veya zarf-fiilden oluşma bu kip biçimleri, aslında Eski Türkçe döneminden bu 
yana gerek tarihî lehçelerimizde gerekse çağdaş lehçelerimizde daima karşımıza çıkan önemli bir özelliktir. Aslında zarf-fiiller, şahsa ve zamana bağlı bir yargı bildirmeden temel cümlenin ya da yan cümlenin yüklemini niteleyerek cümlede genellikle belirteç olarak görev yapan fiilimsilerdir (Bayraktar 2004: 137). Fiil taraflarının yanında belirteç ve bağlama özelliği taşıdıklarından dolayı eylem çekimine giremezler. Ancak yüklem-fiil oluşturmadan soyut bir hareket kavramı anlatabilir; bir esas fiilden sonra gelip yardımcı fiillerle birleşik fiiller kurabilirler. Ayrıca belirteç olarak ilişki kurdukları fiilin anlamını zaman ve durum bakımından da tamamlayabilirler (Korkmaz 2003b: 251). İşte zarf-fiillerin hem eylem vasıflarını devam ettirebilmeleri hem yardımc fiillerle birleşik çekimler oluşturabilmeleri hem de fiilleri nitelerken zaman ve durum ifade edebilmeleri, bazılarının zamanla kip işlevine geçmelerini sağlamıştır. Bugün, gerek tarihî gerek çağdaş Türk lehçelerinin birçoğunda zarf-fiilden oluşma kipler bulunmaktadır. Günümüzde özellikle Kuzey-Batı grubu Türk lehçelerinde, bunların arasında da daha ziyade Kazak Türkçesinde bu özelliği açıkça görebilmekteyiz. Tespitlerimize göre Kazak Türkçesinde yedisi basit, ikisi birleşik olmak üzere toplam dokuz kip bu yapıdadır. Şimdi yukarıda yıldızla işaretlemiş olduğumuz Kazak Türkçesindeki bu zarf-fiil kökenli kipleri tek tek izah etmeye çalışalım.

\section{1. /-AtIn/, /-ytIn/ ekli görülen geçmiş zaman kipi:}

Eklendiği fiile hareketin eski bir zaman diliminde yapılıp bittiği anlamını kazandıran bu kip, açıkça görülen geçmiş zaman çekimini oluşturmaktadır. Ancak bazı durumlarda kip, geniş zamanın veya şimdiki zamanın hikâyesi hatta geniş zaman ve gelecek zaman anlamlarında da kullanılmaktadır. $\mathrm{Bu}$ sebeple de Kazak gramerlerinde "avıspalı ötken şak" (değişken geçmiş zaman) (Kenesbayev vd., 1955: 162; Balakayev vd., 1967: 199), “dağdılı ötken şak” (adet ifadeli geçmiş zaman) (Tüymebayev, 1991: 68), "avıspalı keler şak” (değişken gelecek zaman) (Balakayev vd., 1967: 200) isimleriyle adlandırılmıştır. Kazak Türkçesinin önemli bir sıfat-fiili olan /-AtIn/, /-ytIn/ ekinin, tarihî gelişimi dikkate alındığında ana fiille yardımcı fiili birbirine bağlayıp tasvirî fiiller kuran bağlama zarf-fiilinin -gan sıfat-fiil ekli tur- yardımcı fiiline gelmesiyle /fiil-a+turgan/ ortaya çıktığı ispatlanmıştır: /-a tur-gan/ > /-a tu(r)-gan/ > /-a-tu-gin/ > -atın (Tomanov, 1988: 231), (bar-a tur-gan > bar-atın; aş-a tur-gan > aş-atın gibi). Görüldüğü üzere bu birleşik fiilde asıl fiil, ünlü zarf-fiili ile devamlılık bildiren tur- yardımcı fiiline 
bağlanmış ve nihayet buna -gan sıfat-fiili eklenmiştir. Nitekim bu kuruluştan gelişen -atın eki de, bu -gan sıfat-fiili dolayısıyla geçmiş zaman ifade etmektedir. Ancak bu eski kuruluşu bağlayan zarf-fiil $/-A /$ ve hareketin sürdüğünü gösteren tur- yardımcı fiili de -atın ekine bir geniş zaman anlamı yüklemiştir. Ünlüyle biten fiillerden sonra yardımcı ünsüz ilavesiyle /-y-atın/ şekli beklenirken bunda da bir kısalma olmuş ve ünlüyle biten kök ve gövdelerde /-ytın/, /-ytin/ şekli ekleşmiştir (Öner, 1998: 151-152). Olumsuz şekli ise fiil kök ve gövdelerinden sonra ilave edilen -mA, -bA, -pA olumsuzluk ekleriyle yapılır: "barmaytınmın, ketpeytinsiñ, karamaytın". Son olarak bu kipin günümüz Türk lehçeleri içerisinde sadece Kazak Türkçesinde görüldügünü de belirtelim.

Kipin olumlu ve olumsuz çekimine örnek:

\begin{tabular}{|l|l|}
\hline alatınmın "aldım" & almaytınmın "almadım" \\
\hline alatınsıñ/alatınsız "aldın” & almaytınsıñ/almaytınsız "almadın" \\
\hline alatın "aldı" & almaytın "almadı" \\
\hline alatınbız "aldık" & almaytınbız "almadık" \\
\hline alatınsıñdar/alatınsızdar "aldınız" & almaytınsıñdar/almaytınsızdar "almadını" \\
\hline alatın "aldılar" & almaytın "almadılar" \\
\hline
\end{tabular}

\section{2. $\quad$-(I)p/ ekli öğrenilen geçmiş zaman kipi:}

Türkiye Türkçesindeki -mış, -miş, -muş, -müş ekinin tam karş1lığ1 olarak Kazak Türkçesinde - $p$ zarf-fiil eki ile yapılan öğrenilen geçmiş zaman çekimi; temel olarak söyleyenin, fiilin yapılıp bittiğini kesin olarak bilmediğini, başkasından öğrendiğini belirtmektedir. Ayrıca bu çekim hareketin yapıldığını sonradan fark etme, sonradan anlama veya sonradan görme anlamlarını da ihtiva etmektedir. Bu yüzden Kazak Türkçesinde "Burınğ (Evvelden Olup Bitmiş Zaman) olarak isimlendirilmektedir.

"Fiil-(I) $p+$ tur-ur+şahıs eki" formüllü birleşik fiil çekiminden doğmuş olan bu kipte yer alan gerundiumun çekimli fiil yerini tutması, kendisinden sonra gelen yardımcı fiilin ekleşmesi ya da tamamen düşmesi sebebiyledir (Ergin, 1998: 301). gelüp durursin > gelüpsin "gelmişsin", gelüp durur > gelüpdür "gelmiştir" gibi. Zaten /-(I)p/ zarf-fiil eki Türkçede zaman kavramı olarak kullanılmaya yatkındır. Mesela, "Ayşe mektubu yazıp gönderdi” (yazıp göndermiş, yazıp gönderecek, yazıp gönderir vb.) cümlesi "Ayşe mektubu yazdı ve gönderdi” (yazmış ve göndermiş, yazacak ve gönderecek, yazar ve gönderir) şeklinde de ifade edilebilir. Görüldüğü gibi /-(I)p/ zarf-fiil eki, birlikte kullanıldığı esas fiile zaman kavramı yükleyen bir çekim eki fonksiyonuna 
sahip olabilmektedir (Coşkun, 1999: 187). Ayrıca /-(I)p/ zarf-fiil eki, ulandığ1 fiile esas eylemden önce yapılmış bir eylem anlamı kattığı için daha çok bitmişliği ifade etmektedir (Turgunbayev, 1999: 502): (alıp gitmiş "önce almış sonra gitmiş"; yazıp götürecek "önce yazacak sonra götürecek”; çalışıp kazandı "önce çalıştı sonra kazandı” gibi). Böylece zarf-fiil görevinin yanında eskiden beri bu ek, -Harezmce, Kıpçakça, Çağatayca, Eski Oğuzca, Türkmence, Azerice, Kazakça, Kırgızca, Tatarca, Başkurtça, Kırımca, Karakalpakça, Nogayca, Özbekçe, Yeni Uygurca, Altayca, Hakasça, Şorca ve Tuvaca'daduyulan/öğrenilen geçmiş zaman kipi oluşturma göreviyle kullanılmıştır ve kullanılmaktadır (Ercilasun vd., 2006: 129-343).

Göktürk metinlerinde rastlanılmayan bu yapının Eski Uygurca döneminde sadece Altın Yaruk'ta bir örneğine tesadüf edilmiştir: ... yirtünçüde serilip turur... (Kaya, 1994: 132). Buradaki -ip+turur yapısında şimdiki zaman anlamı vardır. Ayrıca Eski Uygur Türkçesinde - $p$ zarf-fiil ekli esas fiil, er- ek fiilinin görülen geçmiş zaman eki almış şekliyle de birleşir. Bu durumda, esas fiil anlamını muhafaza ederken; - $p$ zarf-fiil eki, duyulan geçmiş zamanda yapılan bir hareketi haber veren şekil ve zaman eki olarak görev yapar. $\mathrm{Bu}$ şekilde meydana gelen duyulan geçmiş zamanla, er- fililinin görülen geçmiş zamanı birleşir ve neticede fiil kipinin gösterdiği oluş ve kılışın geçmiş zamanda gerçekleştiğini bildiren birleşik çekim şekli ortaya çıkar (Coşkun, 1999: 175): Kentü özüm bilmedin yazmış yangılmış ayıg kılınçımnı kentü ökünüp erti yitinçsiz titir : amtı neçök kılayın tip tidim... "Kendi kendim bilmeden hata etmiş yanılmış kötü amelime kendim pişman olmuştum. Bir daha yapmamak üzere vazgeçerim : şimdi nasll yapayım diye dedim..." (Kaya, 1994: $63)$.

Karahanlı Türkçesinde ise sadece Atebetü'l-Hakayık'ta (Divanü'l-Lügati't-Türk ve Kutadgu Bilig'de yok), -p zarf-fiil ekli esas fiil, turfiilinin geniş zaman ekli şekli olan turur yüklemindeki geniş zaman ekinin haploloji yoluyla kaybolması neticesinde meydana gelen -tur/-tür ekiyle birleşir. Bu durumda, esas fiil asıl anlamını muhafaza ederken; - $p$ zarf-fiil eki, duyulan geçmiş zamanda yapılan bir hareketi haber veren şekil ve zaman eki olarak, -tur/tür- eki ise bildirme eki olarak görev yapar (Coşkun, 1999: 175):

ayıbka koyuptur halayık ara,

galat manilerni ayıtmış yana. "birçokları yanlış mana vermiş ve böylece halk arasında utanılacak duruma düşmüştür” (Arat, 1992: 81). 
Kesin çizgilerle Harezm, Kıpçak ve Eski Oğuz dönemlerinde ortaya çıkmış olan bu yapının Harezm Türkçesindeki ilk örneklerinde turur'lu şekiller çoğunluktadır. Kıpçak, Eski Oğuz ve Çağatay Türkçelerinde ise turur'dan hece düşmesiyle oluşmuş -tur'lu biçimler hâkimdir. Kipin açıkça ortaya çıtığı 13. yüzyıldan beri turur ve -tur'un tamamen düştügü biçimler de görülür. Gerek Codexs Cumanicus'ta (kıçkırıp sen), gerek Harezm döneminin ilk eserlerinden Klsasü'l-Enbiya'da (körüp men; kelip siz) turur'suz ve -tur'suz biçimlere de şahit olmaktayız (Ercilasun vd., 2006: 89). Günümüze gelince, yaşayan Türk lehçelerinin bazılarında bu kip halen tur'lu ya da $t u r$ 'dan kısalma $-t \imath /-t i$, $-d l /-d i$ ekleriyle kullanılmaya devam etmektedir. Buna karşın bazı lehçelerde turur ya da tur yapısı tamamen erimiş - $p$ zarf-fiil eki müstakil olarak zaman kavramını belirtir olmuştur. ${ }^{14}$ Kazak Türkçesinde $-p$ zarf-fiil eki tek başına öğrenilen geçmiş zaman kavramını vermekte; sadece 3. şahıs çekimlerinde -tur'dan kısalma - $t l /-t i,-d l /-d i$ eki, kişi eki vazifesiyle karşımıza çıkmaktadır.

Kazak Türkçesinde kipin olumlu ve olumsuz çekimi şu şekildedir:

\begin{tabular}{|c|c|}
\hline alıppın "almışım" & almappın "almamışım" \\
\hline alıpsiñ/alıpsız "almışsın" & almapsıñ/almapsız "almamışsın" \\
\hline alıptı "almış" & almaptı "almamış" \\
\hline alıppız "almışız" & almappız "almamışız" \\
\hline alıpsıñdar/alıpsızdar "almışsınız" & almapsıñdar/almapsızdar "almamışsınız" \\
\hline alıptı "almışlar" & almapt1 "almamışlar" \\
\hline
\end{tabular}

3. /-A/, /-y/ ekli şimdiki zaman kipi:

/-A/, /-y/ zarf-fiil eki Kuzey-Batı (Kıpçak) grubu Türk lehçelerinin tümünde zarf-fiil görevinin yanında fiil çekim eki olarak da görev yapmaktadır. /-A/, /-I/, /-U/ zarf-fiil ekinin istisnai durumlar hariç başlıca görevi esas harekete paralel olarak gerçekleşen bir fiili ifade etmektir. Böylece geldiği fiile süreklilik kazandırır. /- $A /$, /-I/, /-U/ zarf-fiil ekinin zaman açısından süreklilik bildirmesi onun genelde şimdiki zaman içinde yer almasını sağlamıştır. Fiil çekim eki olarak Kazak Türkçesinde şimdiki zaman çekiminde [/fiil/+/zarf-fiil/+/kişi eki/] formülüyle yani fiil $+/-A / / /-y /+k i s ̧ i$ eki biçiminde kullanılmaktadır. Bu çekim aynı zamanda geniş ve gelecek zamanları da ifade edebildiğinden "Avıspalı Osı Şak” (Değişmeli Şimdiki Zaman) veya "Jalpı Osı Şak” (Genel Şimdiki Zaman) isimleriyle adlandırılmıştır: men alamın "alıyorum, alırım, alacağım", sen

${ }^{14}$ Çağdaş Türk Lehçelerinde - $p$ zarf-fiil ekiyle kurulan kip biçimlerini görmek için bkz. Ercilasun vd., 2006: 69-92; Coşkun, 1999: 173-192. 
barasiñ "gidiyorsun, gidersin, gideceksin", men oklymın "okuyorum, okurum, okuyacağım" (Yılmaz, 1998: 118). Böylece kipin /-A/, /-y/ ekli gelecek zaman; /-A/, /-y/ ekli geniş zaman biçimleri de ortaya çıkmıştır.

$\mathrm{Bu}$ şimdiki zaman kipi, aslında /-A zarf-fiil eki+turur/ kalıbının ekleşmesiyle oluşmuştur. Ekleşme derecesi yazı dillerine göre değişmektedir. Bazı yazı dillerinde Kazak Türkçesinde de olduğu gibi tur- fiili tamamen kaybolmuş ve $-A$ zarf-fiil eki kip eki görevini üstlenerek üzerine kişi ekini alabilmiştir. Bu kip, Tuva Türkçesinde şahıs zamirleriyle, Altay Türkçesinde iyelik, diğer yazı dillerinde de zamir kökenli şahıs ekleriyle çekilir; Özbek, Uygur, Kırım, Tatar, Başkurt, Karaçay-Malkar, Kumuk, Nogay, Kırgız, Karakalpak, Kazak, Altay, Hakas, Tuva, Saha ve Çuvaş yazı dillerinde kullanilır (Ercilasun vd., 2006: 129).

Kazak Türkçesinde tur- yardımcı fiili 3. şahıslarda ekleşmiş ve aşınmış olarak korunmaktadır: baradl, keledi, karaydl, aladı, başlaydı vb.

Ek, ünsüzle biten fiillerden sonra /-A/; ünlüyle biten fiillerden sonra /-y/ şeklindedir: aladl, biledi, aytamın; başlaydl, işleydi, karaymın vb.

Kazak Türkçesinde kipin olumlu ve olumsuz çekimleri ise şu şekildedir:

\begin{tabular}{|c|c|}
\hline alamın "aliyorum" & almaymin "almiyorum" \\
\hline alasıñalasız "alıyorsun" & almaysıñ/almaysız "almiyorsun” \\
\hline alad1 "alıyor" & almayd1 "almiyor" \\
\hline alamız "alıyoruz" & almaymiz "almiyoruz" \\
\hline alasıñdar/alasızdar "alıyorsunuz" & almaysıñdar/almaysızdar "almıyorsunuz" \\
\hline aladı "alıyorlar" & almayd1 "almıyorlar" \\
\hline
\end{tabular}

4. [/-(I)p/, /-A/, /-y/ + /otır-/, /jatır-/, /tur-/, /jür-/] kalıplı şimdiki zaman kipi:

Kazak Türkçesinde şimdiki zaman kipinin en sık karşılaşılan bu şekli, fiil kök ve gövdesine $-p,-a,-e,-y$ zarf-fiil eklerinden birinin ilave edilmesinin ardından tur-, jür-, otır-, jatır-, yardımc fiillerinin getirilmesiyle yapılır. Yani bu kip /fiil///-p,-a,-e,-y/+/tur-, jür-, otır-, jatır-/+/kişi eki/ kalıbıla yapılır. Kalıp fiiller olarak tanımlanan tur-, jür-, otır-, jat- fiilleri Kazak Türkçesinde iki işlevle kullanılmaktadırlar: Birincisi temel fiil göreviyle, ikincisi yardımcı fiil göreviyle. Yardımcı fiil olarak kullanıldıklarında temel fiile şimdiki zaman anlamı katarlar. Zaten bu fiillerin anlamlarına baktığımızda dördü de sürüp giden devam eden bir durumu haber vermektedir: tur-: durmak, ayakta 
dikilmek; jür-: yürümek, gitmek; otır-: oturmak; jat-: yatmak, uzanmak. Bu sebeple de fiil çekiminde açıkça şimdiki zamanı meydana getirmektedirler:

Jañbır javıp tur "yağmur yağıyor"

Kırıkşılar koy kırkıp jatır "koyun kırkıcılar koyun kırkıyor"

Saken hat jazıp otır "Saken mektup yaziyor"

Inim üniversitette okıp jür "Erkek kardeşim üniversitede okuyor" (Koç vd., 2004: 261).

Şimdiki zaman çekiminde tur, jür, otır, jatır unsurlarının hangisinin -p, $-a,-e,-y$ zarf-fiillerinden hangisiyle, ne zaman birlikte kullanılacağına dair kesin kurallar yoktur. Bunların kullanım sahaları dili konuşan insanların alışkanlıklarıyla ilgilidir. Ancak bunların kullanım tercihlerinde elbette ki anlamsal ayrıntı farkları bulunmaktadır. A. İskakov bu konuyla ilgili şunları söylemektedir: "Mesela, jañbır javıp tur 'a jañbır javıp jatır da diyebiliriz. Ancak ikisinin anlamları arasında yağma sürecinin birinde daha eskiden, diğerinde ise daha yakın bir zaman diliminde gerçekleşmesi ile ilgili bir anlam farkı bulunmaktadır. Bununla birlikte, jañbır javıp jür veya jañbır javıp otır denilemez. Bu fiillerin nerede kullanılıp nerede kullanılmayacağı dilin kendi içerisinde alışılagelmiş kullanımlarına ve semantik yapısına bağlıdır. $\mathrm{Bu}$ yardımcı fiillerin temel fiillere kattığı anlam, temel fiille bunlar arasında bağlantı kuran zarf-fiillere de bağlıdır. Mesela karap otır ve karay otır; kulak koyıp jür ve kulak koya jür biçimlerinin semantik yapısı da aynı değildir. İlk örneklerde işin dikkatle ve titizlikle yapıldığ işin daha isteksiz ve dikkatsiz bir şekilde yapıldığı vurgulanmaktadır (İskakov, 1991: 260-261). Bu zamanin olumsuzu temel fiile eklenen -p, -a, -e, -y zarf-fiillerinin arkasından ilave edilen tur, jür, otır, jatır unsurlarına /-GAn/ ekinin getirilmesinden sonra, bu ekle kişi ekleri arasına giren jok (yok) kelimesiyle yapılır. Ancak bazı durumlarda fiil kök ve gövdelerinden sonra gelen /-MA/ olumsuzluk ekiyle de tesis edilebilmektedir (Koç vd., 2004: 264).

Kipin olumlu ve olumsuz çekimlerine örnek:

\begin{tabular}{|l|l|}
\hline alıp otırmın "alıyorum" & alıp otırğan jokpın "almıyorum" \\
\hline $\begin{array}{l}\text { alıp otırsıñ/ "alı } \\
\text { alıp otırsız "alıyorsun" }\end{array}$ & $\begin{array}{l}\text { alıp otı̆ğan joksın/ } \\
\text { alıp otırğan joksız "almıyorsun" }\end{array}$ \\
\hline alıp otır "alıyor" & alıp otı̆ğan jok "almıyor" \\
\hline alıp otırmız "alıyoruz" & alıp otırğan jokpız "almıyoruz" \\
\hline $\begin{array}{l}\text { alıp otırsıñdar/ } \\
\text { alıp otırsızdar "alıyorsunuz" }\end{array}$ & $\begin{array}{l}\text { alıp otırğan joksiñdar/ } \\
\text { alıp otırğan joksıdar "almiyorsunuz" }\end{array}$ \\
\hline alıp otır "alıyorlar" & alıp otırğan jok "almıyorlar" \\
\hline
\end{tabular}


5. /-A/, /-y/ ekli gelecek zaman kipi:

Bu kip, /-A/, /-y/ ekli şimdiki zaman çekiminin bazı durumlarda gelecek zaman anlamında kullanılmasından ibarettir. Kipin yapısı /-A/, /-y/ ekli şimdiki zaman bahsinde yukarıda işlenmiştir. Burada kipin sadece olumlu ve olumsuz çekimlerine örnek vermekle yetineceğiz:

\begin{tabular}{|c|c|}
\hline alamın "alacağım" & almaymın "almayacağım" \\
\hline alasıñ/alasız "alacaksın" & almaysiñ/almaysız "almayacaksın' \\
\hline alad1 "alacak" & almayd1 "almayacak" \\
\hline alamız "alacağız" & almaymız "almayacağız" \\
\hline alasıñdar/alasızdar "alacaksınız" & $\begin{array}{l}\text { almaysıñdar/almaysızdar } \\
\text { "almayacaksınız" }\end{array}$ \\
\hline alad1 "alacaklar" & almayd1 "almayacaklar" \\
\hline
\end{tabular}

6. /-A/, /-y/ ekli geniş zaman kipi:

Bu kip de, /-A/, /-y/ ekli gelecek zaman gibi, /-A/, /-y/ ekli şimdiki zaman çekimiyle aynı yapıdadır. Daha doğrusu bu kip /-A/, /-y/ ekli şimdiki zaman çekiminin bazı durumlarda geniş zaman anlamında kullanılmasından ibarettir. Bu sebeple kipin yapısı /-A/, /-y/ ekli şimdiki zaman bahsinde yukarıda işlenmiştir.

Kipin olumlu ve olumsuz çekimlerine örnek:

\begin{tabular}{|l|l|}
\hline alamın "alırım" & almaymın "almam" \\
\hline alasıñ/alasız "alırsın" & almaysıñalmaysız "almazsın" \\
\hline aladı "alır" & almaydı "almaz" \\
\hline alamız "alırız" & almaymız "almayı" \\
\hline alasıñdar/alasızdar "alırsınız" & almaysıñdar/almaysizdar "almazsınız" \\
\hline aladı "alırlar" & almaydı "almazlar" \\
\hline
\end{tabular}

7. Şart Kipi:

Kazak Türkçesinde "Şarttı Ray" (Şartlı Durum) şeklinde isimlendirilen şart kipinin çekimi aynı Türkiye Türkçesinde olduğu gibi /-sA/ ekiyle yapılır. $\mathrm{Bu}$ kipin bazı kullanımlarında şartın dışında dilek anlamı da bulunur. Bu kip dışındaki tasarlama kipleri bağımsız cümleler kurabilirken şart kipi ile ancak bağlı yan cümleler kurulabilmektedir. Kipin hükümlü müstakil bir cümle oluşturması için "şart" değil, "dilek" anlamı taşıması gerekmektedir. Bugün -sa/ -se şart ekinin Eski Türkçedeki -sar/-ser şart ekinin devamı olduğu ve -sar/-ser ekinin de fiilden ya da isimden istek fiilleri türeten bir -sa/-se yapım eki ile geniş zaman ekinin (-r) kaynaşmasından oluştuğu görüşü bilim dünyasında benimsenmiştir: (tapı $\breve{g}+s a-$ "hizmet arzusunda olmak"; ülig-se- "ölmek 
istemek" gibi) (Korkmaz, 1995: 164-165). Ancak -sar/-ser ekinin ilk yaz1lı metinlerimizden Göktürk anıtlarında tam bir zarf-fiil eki olarak kullanılması ve şahıs ekleri alarak henüz bir şart çekimi oluşturmamış olması (Ercilasun vd. 2006: 693-694) bu kipi de zarf-fiil kökenli kipler arasına almamızı gerektirdi. Kaldı ki bugün bile, bağımlı yan cümle kuran şart ekinin kip değil zarf-fiil olduğunu savunan bilginlerimiz vardır (Gülsevin, 1990: 276-279; Karahan, 1994: 471-474). Fakat zarf-fiillerin şahıs ekleri alarak yüklem çekimi oluşturamayacağı fikrinden hareketle bu yapının günümüzde kip olarak değerlendirilmesi daha makul görünmektedir (Öner, 1999: 834). -sar/-ser eki, Göktürk metinlerinde zarf-fiil eki olarak içinde "şart" kavramı da bulunduran "-dıkça, -dığı sürece, -dığı zaman" anlamlarını taşımaktadır: (Ol yirgerü barsar Türk budun ölteçi sen. Ötüken yir olurup arkış tirkiş 1sar neng bungug yok. Ötüken yış olursar benggü il tuta olurtaçı sen. "O yere varırsan/vardığında Türk milleti öleceksin. Ötüken yerinde oturup kervan gönderdikçe/gönderirsen hiç sıkıntın olmaz. Ötüken yaylasında oturdukça/oturursan ebediyen il tutarak oturacaksın) (Ergin, 1994: 66). Eski Uygurcada da ek -sar/-ser şeklindedir fakat artık şahıs eklerine bağlanmaya başlamış ve şart çekimi oluşmuştur. -sar/-ser ekindeki $-r$ düşmesi Eski Türkçe döneminde başlamış ve Orta Türkçe döneminde tamamlanmıştır. Kutadgu Bilig'de şart kipi artık kurallı olarak -sa/-se' dir. Şahıs zamirleri veya ekleşmiş şahıs zamirleri alarak yardımcı şart cümleleri kurmuştur (Korkmaz, 1995: 160). Ek, Orta Türkçe devresinden itibaren dilek kipi anlamını da ifade etmeye başlayarak bağımsız cümleler kurabilmiştir. XIII. yüzyılın sonlarından itibaren ise kip, zamir menşeli şahıs ekleri yerine iyelik menşeli şahıs ekleriyle çekimlenir olmuştur (Korkmaz, 1995: 164-165). Bu kip günümüzde sadece Kazak Türkçesinde değil, tüm çağdaş Türk lehçelerinde dilek-şart kipi olarak kullanılmaktadır. Şart ekinin Göktürkçe döneminde açıkça zarf-fiil olarak kullanılırken tedricî bir gelişmeyle kip kategorisine geçmesi ve şahıs ekleri alarak çekime girmesi, Türkçede zarf-fiillerin zamanla kipleşmesi olayına bizce güzel bir örnektir.

Kipin olumlu ve olumsuz çekimlerine örnek:

\begin{tabular}{|c|c|}
\hline alsam "alsam" & almasam "almasam" \\
\hline alsañ/alsañız "alsan" & almasañ/almasañız "almasan" \\
\hline alsa "alsa" & almasa "almasa" \\
\hline alsak "alsak" & almasak "almasak" \\
\hline alsañdar/alsañıdar "alsanız" & almasañdar/almasañıdar "almasanız” \\
\hline alsa "alsalar" & almasa "almasalar" \\
\hline
\end{tabular}




\section{Rivayet Birleşik Çekimi:}

Kazak Türkçesinin rivayet birleşik çekimi Türkiye Türkçesinden farklı olarak "imiş" yerine "eken" ile yapılır. "eken" aslında er- fiilinin (ek eylemin) partisip kaynaklı -GAn ekli geçmiş zaman (öğrenilen geçmiş zaman) çekiminden türemiştir: (er-ken > e-ken / i-ken > eken / iken / -ken). (Öner 1999: 834; Banguoğlu 1998: 480; Deny 1941: 433, 908) Ancak bu çekim zamanla gerundiumlaşarak Orta Türkçe devresinden itibaren (eken / iken / -ken) şeklinde zarf-fiil olarak kullanılır olmuştur. Özellikle tarihî Kıpçak lehçesi döneminde “-ken” ekinin belirgin bir şekilde zarf-fiil olarak kullanılmas1 ${ }^{15}$ günümüz Kıpçak lehçelerinden olan Kazak Türkçesinin rivayet birleşik çekimini de zarf-fiil kökenli kipler arasına almayı zorunlu kılmaktadır. “-ken”, bugün de başta Türkiye Türkçesi olmak üzere birçok lehçede işlek bir zarf-fiil eki olarak kullanılmaya devam etmekte (Ercilasun vd. 2007) ve “-ken”, cevher fiilinin zarf-fiili olması hasebiyle fiillerin de birleşik zarf-fiillerini meydana getirmektedir (Aydın 2000: 644): (almış-ken, alır-ken, almaz-ken, allyor-ken, almakta-iken, alacak-ken, almall-y-ken gibi). Kazak Türkçesinde rivayet birleşik zamanının "eken” sözcüğüyle kurulması diğer Doğu grubu lehçelerinde de görülmektedir. Hatta Oğuz grubu lehçelerinden olan Türkmencede de bu kipin eken'le çekime girdiğine şahit olmaktayız (İlker, 1997: 135).

Rivayet birleşik çekimi, /-p/ ekiyle kurulan öğrenilen geçmiş zamanın rivayet çekimi dişında diğer bütün basit kiplerde görülebildiği için burada sadece Kazak Türkçesinde en yaygın olan birleşik çekimlerden birisini örnek olarak vereceğiz.

/-Ar/, /-r/ ekli geniş zamanın olumlu ve olumsuz rivayetine örnek:

\begin{tabular}{|l|l|}
\hline alar ekenmin "alırmışım" & almas ekenmin "almazmışım" \\
\hline $\begin{array}{l}\text { alar ekensiñ / } \\
\text { alar ekensiz "alırmışsın" }\end{array}$ & $\begin{array}{l}\text { almas ekensiñ / } \\
\text { almas ekensiz "almazmışıı" }\end{array}$ \\
\hline alar eken "alırmış" & almas eken "almazmış" \\
\hline alar ekenbiz "alırmışım" & almas ekenbiz "almazmışım" \\
\hline $\begin{array}{l}\text { alar ekensiñder / } \\
\text { alar ekensizder "alırmışsınız" }\end{array}$ & $\begin{array}{l}\text { almas ekensiñder / } \\
\text { almas ekensizder "almazmışsınız" }\end{array}$ \\
\hline alar eken "alırmışlar" & almas eken "almazmışlar" \\
\hline
\end{tabular}

15 “e- / i- yardımcı fiilinin zarf-fiil şekli olan ve cevher fiilinin düşmesi ile ekleşerek bir birleşik zarf-fiil eki hâlini alan -ken'e, eski Kıpçak Türkçesi metinlerinde şimdiki zaman kipinde rastlanmaktadır: "başlayyor-ken, keleyor-ken, keteyor-ken, yumruklayyor-ken" vs. (bkz. Karamanlıŏlu 1994: 148). 


\section{9. $\quad$ Şart Birleşik Çekimi:}

Yukarıda yedinci maddede şart kipi ile ilgili getirdiğimiz izahlar bu kip çekimi için de aynen geçerlidir. Burada ek olarak şunu belirtmemiz gerekir ki; şart birleşik kipi çağdaş Türkiye Türkçesinde "ise" yapısıyla kurulurken, günümüz Kazak Türkçesinde bol- fiilinin şart eki almış hâli olan "bolsa" sözcügüule yapılır. Bu birleşik çekimle oluşan yapılar, cümlenin temel fiille bağlantısını kurarak bir anlamda onun bütünleyiciliği görevini yerine getirir. Kazak Türkçesinde birleşik şart çekiminin öğrenilen geçmiş zaman, emir, şart ve istek kipleriyle çekimi bulunmamaktadır (Koç, 2004: 306).

/-GAn/ ekli görülen geçmiş zamanın olumlu ve olumsuz şartına örnek ${ }^{16}$ :

\begin{tabular}{|c|c|}
\hline alğan bolsam "aldıysam/almışsam" & $\begin{array}{l}\text { almağan } \\
\text { "almadıysam/almamışsam" bolsam }\end{array}$ \\
\hline $\begin{array}{l}\text { alğan bolsañ// } \\
\text { alğan bolsañız "aldıysan/almışsan" }\end{array}$ & $\begin{array}{l}\text { almağan bolsañ/ } \\
\text { almağan } \\
\text { "almadıysan/almamışsan", }\end{array}$ \\
\hline alğan bolsa "aldıysa/almışsa" & almağan bolsa "almadıysa/almamışsa" \\
\hline alğan bolsak "aldıysak/almışsak" & \begin{tabular}{|l|} 
almağan \\
"almadıysak/almamışsak"
\end{tabular} \\
\hline $\begin{array}{l}\text { alğan bolsañdar/ } \\
\text { alğan bolsañızdar } \\
\text { "aldıysanız/almışsanız" }\end{array}$ & $\begin{array}{l}\text { almağan bolsañdar/ } \\
\text { almağan bolsañızdar } \\
\text { "almadıysanız/almamıșsanız" }\end{array}$ \\
\hline alğan bolsa "aldıysalar/almışsalar" & $\begin{array}{l}\text { almağan } \\
\text { "almadıysalar/almamışsalar" }\end{array}$ \\
\hline
\end{tabular}

\section{Sonuc}

Cümlede yüklemin anlamını çeşitli yönlerden etkileyen, fiillerden bazı eklerle yapılmış, şahıs ve zaman belirtmeyen zarf görevinde kelimeler olarak tanımlanan zarf-fiiller, tarihî ve çağdaş Türk lehçelerinde aslî görevlerinin yanında başka birtakım işlevlere de sahiptirler. Bu işlevlerin en önemlilerinden birisi de zarf-fiillerin, kip çekimlerini oluşturan unsurlar arasında yer almasıdır. Bugün Türk lehçelerinin önemli bir kısmında özellikle de Kuzey-Batı (Kıpçak) grubu Türk yazı dillerinde, bunların içerisinde de bilhassa Kazak Türkçesinde bu durum açıkça görülmektedir. Yukarıda yaptığımız açıklamalar ve örneklerde görüldüğü üzere Kazak Türkçesinde yedi basit, iki birleşik çekim olmak üzere toplam dokuz kip zarf-fiil soyludur:

\section{1. /-AtIn/, /-ytIn/ ekli görülen geçmiş zaman kipi,}

${ }^{16}$ Kazak Türkçesindeki /-GAn/ ekli görülen geçmiş zamanın şartı, Türkiye Türkçesindeki -mIşs ise birleşik çekiminin verdiği anlamı da ihtiva ettiği için örneklerin yanına her iki anlam da yazılmıştır. 
2. /-(I)p/ ekli duyulan/öğrenilen geçmiş zaman kipi,

3. /-A/, /-y/ ekli şimdiki zaman kipi,

4. [/-(I)p/, /-A/, /-y/ + /otır-/, /jatır-/, /tur-/, /jür-/] kalıplı şimdiki zaman kipi,

5. /-A/, /-y/ ekli gelecek zaman kipi,

6. /-A/, /-y/ ekli geniş zaman kipi,

7. Şart kipi,

8. Rivayet birleşik çekimi,

9. Şart birleşik çekimi

Siralanan kiplere bakıldığında /-A/, /-I/, /-U/, /-y/ ve /-(I)p/, /-(U)p/ zarf-fiil eklerinin başta /tur-/ yardımc1 fiili olmak üzere /otır-/, /jatır-/, /tur-/, /jür-/ yardımcı filleriyle çeşitli tasvirî birleşik fiil çekimleri kurduğu ve bu birleşik çekimlerin zamanla aşınarak işlev değiştirip çeşitli kip kategorileri oluşturduğu görülmektedir. Yukarıdaki ilk 6 kip bu şekilde meydana gelmiştir. 7. ve 9. maddelerdeki şart çekimi ise Eski Türkçedeki -/sAr/ zarf-fiil ekinin aşınması ve işlev değiştirmesiyle oluşmuştur. 8. maddedeki rivayet çekimi de /-iken/ zarf-fiilinden gelmektedir. Bu durum, zarf-fiillerin Türkçenin kıvrak cümle yapısına renk katmalarının yanında Türk dilinin zengin kip kategorisinin daha çeşitlenmesine katkıda bulunduklarının da bir kanıtıdır.

\section{Kaynakça}

Arat, Reşit Rahmeti (1992), Atebetü'l-Hakaylk (Edib Ahmed B. Mahmud Yükneki), Ankara: TDK Yay.

Atabay, Neşe; Özel, Sevgi; Kutluk, İbrahim (2003), (Yöneten ve Yayıma Hazırlayan: AKSAN, Doğan), Sözcük Türleri, İstanbul: Papatya Yay.

Aydın, Mehmet (2000), "Anadolu Ağızlarında iken, -ken Zarf-Fiilinin Kullanımı ve Görevleri”, Türk Dili, Sayı: 588, Aralık: s.639-645.

Balakayev, M.; Kordabayev, T.; Hasenova, A.; İskakov, A. (1967), Kazak Tilinin Grammatikast-I, Morfologiya, Almatı.

Banguoğlu, Tahsin (1998), Türkçenin Grameri, Ankara: TDK Yay.

Bayraktar, Nesrin (2004), Türkçede Fiilimsiler, Ankara: TDK Yay.

Buluç, Sadettin (1988); “Türk Dilinin Tasnifi”, İslam Ansiklopedisi, Türkler-Türk Dili maddesi, İstanbul: Milli Eğitim Basımevi, Cilt: 12/2, s.456-468. (Bu yazı Reşit Rahmeti ARAT'ın Türkiyat Mecmuası, Sayı: 10, s.59-139'daki makalesinden özetle hazırlanmıştır.)

Buran, Ahmet; Alkaya, Ercan (2001), Çağdaş Türk Lehçeleri, Ankara: Akçağ Yay. 
Coşkun, Volkan (1999), "Türk Lehçelerinde Zaman Kavramı Taşıyan -p Zarf-Fiil Eki”, Türk Dünyası Dil ve Edebiyat Dergisi, Bahar, Sayı: 7, Ankara: TDK Yay., s.173-192.

Çengel, Hülya Kasapoğlu (2005), Kırgız Türkçesi Grameri, Ankara: Akçağ Yay.

Davlatov, S.; Kudaybergenov, S. (1980), Azırkı Kırgız Tili, Morfologiya, Frunze.

Deny, Jean (1941), Türk Dili Grameri (Osmanlı Lehçesi), (Çev. Ali Ulvi Elöve), İstanbul: Maarif Vekâleti Neşriyatı

Doğan, Levent vd.(2007), Çağdaş Türk Lehçeleri El Kitabı, İstanbul: Kriter Yay.

Ercilasun, Ahmet Bican vd.(1991), Karşılaş̧tırmalı Türk Lehçeleri Sözlüğü, Cilt I, II, Ankara: Kültür Bakanlığı Yay.

Ercilasun, Ahmet Bican; Karahan, Leyla; Kiriş̧̧ioğlu, M. Fatih (Redaksiyon) (2006), Karşılaştırmall Türk Lehçeleri Grameri I -Fiil- "Basit Çekim", Ankara: TDK Yay.

Ercilasun, Ahmet Bican (Editör) (2007), Türk Lehçeleri Grameri, Ankara: Akçağ Yay.

Ergin, Muharrem (1994), Orhun Abideleri, İstanbul: Boğaziçi Yay.

Ergin, Muharrem (1998), Türk Dil Bilgisi, İstanbul: Bayrak Yay.

Gülsevin, Gürer (1990), “Türkçede -sa Şart Gerundiumu Üzerine”, Türk Dili, Sayı: 467, Kasım, Ankara: TDK Yay., s. 276-279.

Gülsevin, Gürer (2000), “Türkiye Türkçesindeki Zaman ve Kip Çekimlerinde Birleşik Yapılar Üzerine”, TDAY-Belleten, Ankara: TDK Yay., s. 215-224.

Hangildin, V. N. (1959), Tatar Tili Grammatikasl, 'Morfologiya Hem Sintaksis', Kazan. İlker, Ayşe (1997), Batı Grubu Türk Yazı Dillerinde Fiil, Ankara: TDK Yay.

İskakov, Ahmedi (1991), Kazirgi Kazak Tili, Almatı.

İsabekova, Y. K. vd. (2001), Kazak Tili, Almatı.

Karahan, Leyla (1994), “-sa, -se Eki Hakkında”, Türk Dili, Sayı: 516, Aralık, Ankara: TDK Yay., s. 471-474.

Karamanlığlu, Ali Fehmi (1994), Kipçak Türkçesi Grameri, Ankara: TDK Yay.

Kaya, Ceval (1994), Uygurca Altun Yaruk (Giriş, Metin ve Dizin), Ankara: TDK Yay.

Kenesbayev, S.; İskakov, A.; Ahanov, K. (1955), Kazak Tili Grammatikası, (I. Bölim), Almatı.

Koç, Kenan; Doğan, Oğuz; (Redaktör: Ayabek Bayniyazov) (2004), Kazak Türkçesi Grameri, Ankara: Gazi Kitabevi

Korkmaz, Zeynep (1995), “-sa/-se Dilek-Şart Kipi Eklerinde Bir Yapı Birliği Var mıdır?”, Türk Dili Üzerine Araştırmalar, C. I, Ankara: TDK Yay., s. 160-167.

Korkmaz, Zeynep (2003a), Türkiye Türkçesi Grameri (Şekil Bilgisi), Ankara: TDK Yay.

Korkmaz, Zeynep (2003b), Gramer Terimleri Sözlügü, Ankara: TDK Yay.

Oruzbayeva, B.; Kudaybergenov, S. (1964), Kırgız Tilinin Grammatikası 'Morfologiya', Frunze.

Öner, Mustafa (1998), Bugünkü Kıpçak Türkçesi, Ankara: TDK Yay. 
Efendioğlu, S. / Sosyal Bilimler Araştırmaları Dergisi. 1, (2010): 1-20

Öner, Mustafa (1999), “-mat1/-meti Gerundiumu Hakkında", 3. Uluslar arası Türk Dil Kurultayı Bildirileri, Ankara: TDK Yay., s. 833-840.

Tekin, Ayşe (2006), Kazak Türkçesinde Sıfat-Fiil ve Zarf-Fiil Ekleri, Yayımlanmamış Yüksek Lisans Tezi, Trakya Üniversitesi, Edirne.

Tomanov, M. (1988), Kazak Tilinin Tarihi Grammatikası, Almatı.

Turgunbayev, Caştegin (1999), "-a turur Şimdiki Zaman ve -p turur Geçmiş Zaman Eklerinin Yapısı Üzerine”, Türk Dünyası Dil ve Edebiyat Dergisi, Güz, Sayı: 8, Ankara: TDK Yay., s. 497-505.

Türk Gramerinin Sorunları II (1999), "Türkçede Fiil ve Fiil Çekimi”, Ankara: TDK Yay., s.45-112.

Tüymebayev, J. (1991), Kazak Tili, (Grammatikalık Anıktagış), Almatı.

Yılmaz, Hikmet (1998), Kuzey (Kıpçak) Grubu Türk Şivelerinde Zarf-Fiiller, Yayımlanmamıs Doktora Tezi, Erciyes Üniversitesi, Sosyal Bilimler Enstitüsü, Kayseri.

Yüce, Nuri (1988); “Türk Dili ve Lehçeleri”, İslam Ansiklopedisi, Türkler-Türk Dili maddesi, İstanbul: Milli Eğitim Basımevi, Cilt: 12/2, s.468-530. 